\title{
Reflection on Customer Satisfaction Using the Jaket Application in Terms of Aspects of E-Service Quality, Price, and Brand Awareness
}

\author{
Acai Sudirman \\ acaivenly@stiesultanagung.ac.id \\ Sekolah Tinggi Ilmu Ekonomi Sultan Agung \\ Fitria Halim \\ fitriahalim2839@stiesultanagung.ac.id \\ Sekolah Tinggi Ilmu Ekonomi Sultan Agung \\ Onita Sari Sinaga \\ onitasari@stiesultanagung.ac.id \\ Sekolah Tinggi Ilmu Ekonomi Sultan Agung \\ Fenny Krisna Marpaung \\ fennykrisnamarpaung@unprimdn.ac.id \\ Universitas Prima Indonesia
}

\begin{abstract}
The need for fast transportation services has caused several businesses to try to create application-based transportation applications according to market demand. To answer this market need, application-based transportation is needed that can implement e-service quality and provides prices following consumer expectations so that it is expected to be able to foster strong brand awareness of the application. The purpose of this study is to analyze the contribution of e-service quality, price, and brand awareness to customer satisfaction. This research was conducted by distributing 180 questionnaires to active users of the Jacket application and only 120 questionnaires that can be used. Tests were carried out with the help of statistical tools in the form of Structural Equation Modeling (SEM) based on Partial Least Square. The results showed that e-service quality has a significant positive effect on customer satisfaction. The results of further research show that price has a positive but not significant effect on customer satisfaction. As for the results of the last study, it was found that brand awareness had a significant positive effect on customer satisfaction.
\end{abstract}

Keywords : brand awareness, customer satisfaction, e-service quality, price

\section{Introduction}

One of the fundamentals of the success of the marketing system for a product lies in the readiness of the content to be demonstrated or promoted to the general public. The existence of the current business model cannot be separated from market connectivity which is connected with technological developments. The development of the online business world, of course, has implications for new differentiation for creating and marketing goods and services. One of the fields with the application of a marketing system that is oriented towards technological development is the transportation sector (Sudirman et al., 2020). Transportation is one element that has an important role in terms of activities and helps humans in terms of mobility for daily life. So that matters regarding transportation must be prepared carefully because it has a big share in the smooth running of daily activities (Karmila \& Sunia, 2020).

One of the application-based transportation that is present in the community today is the Jaket application. The Jaket application is an application-based transportation that specifically presented in Pematangsiantar City to help meet the needs of everyday consumers. The 
manifestation of the tagline presented by the Jaket application is "Serving You with Satisfaction Guarantee is Our First Priority at the Front" (Jasakreta, 2021). One of the advantages of the Jaket application lies in ordering and delivering orders that can serve more than 1 shopping place including goods shopping services, food shopping services, people-to-people services, transfer services, money transfer services, photocopy services, photo printing services, cake buying services birthday and so on (Jasakreta, 2021). The main purpose of the Jaket application is to meet consumer expectations in using application-based transportation. The manifestation of fulfilled expectations is the level of customer satisfaction with the application. Therefore, to grow and maintain customer satisfaction, credible instruments are needed to encourage it, such as the application of e-service quality, price quotes, and brand awareness of these applications.

Service quality in e-commerce can be defined as the overall evaluation and assessment of consumers on the advantages and offerings of electronic service quality in virtual markets (Santos, 2003). The expected output is less than acceptable if requirements are higher than results, and consumer frustration thus exists (Zehir \& Narclkara, 2016). However, it was finally realized that if this new technology were to be used as a distribution channel, consumer needs and customer satisfaction would become as important as ever and a higher quality of e-Service has been considered as one of the main entrepreneurial targets Barrutia et al. (2009). As a determinant of the success or failure of electronic retailers, the efficiency of web-based services is very important, where e-service quality demonstrates how an e-commerce platform supports and promotes online shopping, ordering and shipping (Berliana \& Zulestiana, 2020).

Apart from the e-service quality factor, the price factor is an important element in shaping customer satisfaction. The price variable can determine whether consumers will be willing and able to buy a product (Anggraini \& Budiarti, 2020). In general, consumers will use price as an indicator of satisfaction, because these consumers will check the price of a product offered before carrying out activities to buy (Sudirman, Halim, \& Pinem, 2020). Price is one of the most basic things in creating satisfaction for consumers. If the price offered by the vendor is in line with expectations, then the consumer will decide to buy a product. It is better if the price offered is not by the expectations of consumers, so consumers will not buy it (Caniago et al., 2019). This is what underlies the great pleasure of price sensitivity when using applicationbased transport (Lie et al., 2019).

Furthermore, the brand awareness factor is an important thing to pay attention to when it comes to growing customer satisfaction. The implementation of branding is very important to be applied to business units, especially in the application-based transportation sector, especially because of the customer's desire for predictable product and service experiences (Barreda, et al.,, 2015). Overall, the intangible essence of commodities in the world of service marketing makes branding a significant phenomena (Wibowo, et al., 2018). Brands form a set of expectations in the minds of consumers whose implications will provide a level of satisfaction through purchasing behavior (Surucu et al., 2019). Awareness of a product brand has an important role in helping the comparison between product performance and consequent purchases (Herrera \& Blanco, 2011). Research by Valkenburg \& Buijzen (2005), said brand awareness is a reflection of the customer's knowledge of a particular brand name and previous exposure to that brand.

Grabbing the market share of these application users is not easy, because the Jaket application has just been launched and is specifically intended for users in Pematangsiantar City. This is a challenge in itself for the Jaket application as one of the local transportation in Pematangsiantar City so that it can compete competitively with the Gojek and Grab applications. This research is presented to provide new knowledge related to consumer satisfaction of users of the Jaket application as application-based transportation. The state of the art of this research lies in the object of research, namely consumer satisfaction of the Jaket application users, which previously had no research that discussed this. On this basis, The researcher tries to examine the role of e-service quality provided by the Jaket application with the orientation of the pricing of the application and how the performance of brand awareness affects the level of consumer satisfaction. The urgency of this study is to determine the contribution of e-service quality, price, and brand awareness to consumer satisfaction of Jaket application users. 


\section{Literature Review}

Implementation of service quality under consumer expectations and consistency in maintaining customer satisfaction are the success factors of a company to achieve a competitive advantage (Suprapti \& Suparmi, 2020). The manifestation of e-service quality is defined as the extent to which a website facilitates the use of something efficiently and effectively (Hernita, Sidik, \& Sanjaya, 2020). E-Service quality on a website has a significant effect on customer satisfaction because the experience of customers using the website in making transactions makes customers feel immediately good and bad about e-service quality (Bandawaty, Huriyati, \& Dirgantari, 2020). Representatives of service quality can be interpreted as a breakthrough from a marketplace to provide services or an efficient and effective shopping facility or transaction, purchase, and delivery to satisfy customers which will affect the level of customer satisfaction (Berliana \& Zulestiana, 2020). Measurement items for e-service quality latent variables consist of tangibles, reliability, responsiveness, assurance, empathy, efficiency, fulfillment, system availability and privacy which were adapted from research by Pradana \& Sanaji (2018). Several research results that examine e-service quality have been studied by several researchers and present different research results. Research by Sukirno, Aulawi, \& Widiawati (2019), Bandawaty et al. (2020), Puriwat \& Tripopsakul (2017), state that there is a significant effect of the implementation of e-service quality on customer satisfaction. While the research results from(Berlianto, 2017), delivering e-service quality has no significant effect on customer satisfaction.

\section{H1: E-service quality affects customer satisfaction}

Consumers are people who receive the work or production of a company, so creating customer satisfaction is the goal of a company for the survival of the company itself (Sudirman et al., 2020). To meet customer satisfaction, the company must also pay attention to the price offered to customers and what will be obtained at this price (Salim \& Nurdin, 2020). Price is an important factor for companies to get profit and also to attract customers In general, consumers will use price as an indicator of satisfaction, because these consumers will check the price of a good or service being offered before deciding to buy (Caniago et al., 2019). The manifestation of price-fixing can be said to be a measure of the medium of exchange for obtaining ownership rights or use of a product or service (Anggraini \& Budiarti, 2020). Measurement items for price latent variables consist of affordability of prices, match price with quality, price competitiveness, and price match with benefits which were adapted from research (Fure, 2013). Several research results that examine prices have been examined by many researchers and present different research results. Research by Anggriana et al. (2017), Rahayu \& Riana (2020), and Sianipar (2019), states that there is a significant effect of pricing on customer satisfaction. While the research results from(Rondonuwu, 2013), conveying the price does not have a significant effect on customer satisfaction.

\section{H2:Price affects customer satisfaction}

Raising awareness is a mechanism for expanding the brand market. Consciousness also affects perceptions and behavior, which implications will be felt on the level of consumer satisfaction. Brand awareness is the key to brand assets or the opening key to entering other elements (Amalia et al., 2014). After the desire for a product category is created, then companies need to direct their efforts towards creating awareness of a brand (Ariowibowo et al., 2018). The consideration that is carried out as an initial step for purchasing decisions is to ensure that the product brand to be purchased conforms to the criteria (Putri \& Happy, 2019). Decisions made by customers about a product tend to be fast if they already know and understand a particular product brand (Putri \& Happy, 2019). Measurement items for e-service quality latent variables consist of brand familiarity and brand recognition which were adapted from research (Foroudi, 2018). Several research results that examine brand awareness have been studied by many researchers and present different research results. Research by Ramadania et al., (2020), Darmawan (2019), and Yulianto (2021), states that there is a significant effect of brand awareness on customer satisfaction. While the research results from (Maulida \& Indah, 2020), conveying brand awareness has no significant effect on customer satisfaction.

\section{H3:Brand awareness affects consumer satisfaction}




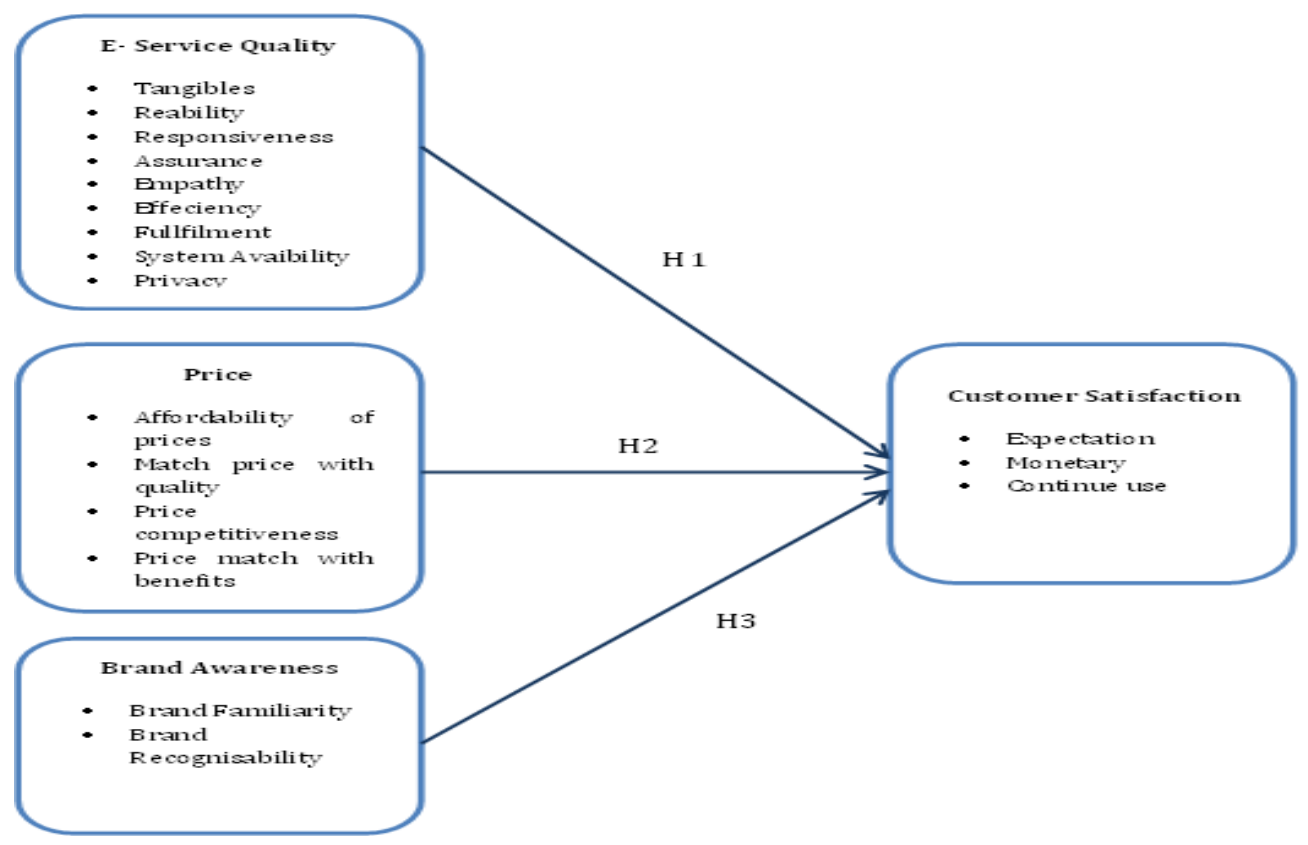

Figure 1. Research Model

\section{Research methodology}

Researchers used an associative quantitative approach. This study uses a questionnaire instrument which is carried out cross-sectional or at a certain time. The scale used is the Likert scale, which is a tiered measurement scale. The sampling technique used was purposive sampling, which conducted research on a group of subjects with certain characteristics or who were considered closely related to previously known population characteristics. The population used in this study were the users of the Jaket application in Pematangsiantar City. Due to the unknown population size, the number of samples determined using the convenience sampling technique. According to (Hair, 2014), the sample size is at least 5 times the number of indicators. Furthermore, Hair (2014) also suggest that the appropriate sample size ranges from 100-200 respondents. Statistical testing in this study was carried out with the help of the Structural Equation Modeling (SEM) statistical tool based on Partial Least Square. The validity test is used to measure whether or not the inductor item in a questionnaire is valid. The validity test in this study uses convergent validity by looking at the minimum value of the factor loading indicator for each indicator item $\geq 0.6$ (Sarwono, 2016). The next reliability test is by looking at the Cronbach's Alpha value and the Composite Reliability value which is used to measure internal consistency in the data reliability test, as well as the AVE (Average Variance Extracted) value as the mean percentage of variant scores extracted from a set of latent variables which are estimated through standardized loading. For this test, the researcher will also use the Composite Reliability value limit> 0.7 and Cronbach's Alpha> 0.6, and the AVE value> 0.5 (Sarwono, 2016). 


\section{Analysis and Discussion}

\subsection{Data Analysis}

\subsubsection{Descriptive Analysis of Respondents}

The questionnaire was distributed online via WhatsApp and Telegram social media. Social media was chosen because many of the target respondents were actively using social media in their daily lives. Of the 180 responses received, only 120 data (66.67\%) were considered valid for the study. In general, the characteristics of the respondents can be explained in table 1 below:

Table 1. General Profile of Respondents

\begin{tabular}{|c|c|c|c|}
\hline Category & Detail & amount & Percentage \\
\hline Gender & $\begin{array}{c}\text { Men } \\
\text { Woman }\end{array}$ & $\begin{array}{l}56 \\
64\end{array}$ & $\begin{array}{l}46.67 \% \\
53.33 \%\end{array}$ \\
\hline Age & $\begin{array}{l}15-24 \text { years } \\
25-34 \text { years } \\
35-44 \text { years } \\
45-54 \text { years }\end{array}$ & $\begin{array}{l}25 \\
45 \\
38 \\
12 \\
\end{array}$ & $\begin{array}{c}20.83 \% \\
37.5 \% \\
31.67 \% \\
10 \% \\
\end{array}$ \\
\hline Education & $\begin{array}{l}\text { High school } \\
\text { D1 to D3 } \\
\text { S1 } \\
\text { S2 } \\
\end{array}$ & $\begin{array}{c}61 \\
33 \\
24 \\
2 \\
\end{array}$ & $\begin{array}{c}50.83 \% \\
27.5 \% \\
20 \% \\
1.67 \% \\
\end{array}$ \\
\hline Profession & $\begin{array}{c}\text { College student } \\
\text { Employees } \\
\text { Teacher } \\
\text { Entrepreneur } \\
\text { Government employees } \\
\text { Others } \\
\end{array}$ & $\begin{array}{c}4 \\
21 \\
14 \\
29 \\
10 \\
4 \\
\end{array}$ & $\begin{array}{c}35 \% \\
17.5 \% \\
11.67 \% \\
24.17 \% \\
8.33 \% \\
3.33 \% \\
\end{array}$ \\
\hline Income & $\begin{array}{c}<\text { IDR } 1,000,000 \\
\text { IDR } 1,000,000-\text { IDR } 5,000,000 \\
\text { IDR } 5,000,000-\text { IDR } 9,000,000 \\
>\text { IDR } 10,000,000\end{array}$ & $\begin{array}{c}34 \\
61 \\
18 \\
7\end{array}$ & $\begin{array}{c}28.34 \% \\
50.83 \% \\
15 \% \\
5.83 \% \\
\end{array}$ \\
\hline $\begin{array}{l}\text { The frequency of using } \\
\text { JACKET in a month }\end{array}$ & $\begin{array}{c}1 \text { time } \\
\text { 2-5 times } \\
\text { 5-10 Times } \\
>10 \text { Times }\end{array}$ & $\begin{array}{c}41 \\
56 \\
17 \\
6\end{array}$ & $\begin{array}{c}34.16 \% \\
46.67 \% \\
14.17 \% \\
5 \% \\
\end{array}$ \\
\hline
\end{tabular}

Source: Data Processed (2020)

Based on Figure 1 above, it is known that the majority of Jaket application users are female with a percentage of (53.33\%). From the educational aspect of the Jaket application, the majority of users are high school education users (59.83\%). From the professional aspect, students (35\%) are the majority users of the Jaket application with the orientation of using Jaket in a month ranging from 2-5 times (46.67\%).

\subsubsection{Outer Model Analysis}

In testing the outer model, validity checks and reliability tests are the experiments carried out. The loading factor and AVE are calculated by convergent validity checking, provided that the loading factor is above 0.7 and the AVE value is 0.5. (Hair, 2014). Model reliability testing according to (Hair, 2014) is seen from the value of cronbanch's alpha and composite reliability (CR) which has a value greater than 0.7 . The following describes the results of the outler model analysis (see Table 2): 


\subsubsection{Research Hypothesis Analysis}

In addition, a significance test is used to assess the relationship between exogenous variables and endogenous variables to illustrate the hypothesis test. The importance criterion is seen from the p-value. With a significance level of 5\%, if the p-value between the exogenous and endogenous variables is less than 0.05 , it means that the exogenous variable has a significant effect on the endogenous variable, on the other hand, if the value is greater than 0.05 , it means that the exogenous variable has no significant effect in building endogenous variables.

Table 3. Hypothesis Test Results

\begin{tabular}{|c|c|c|c|c|}
\hline Path Between Variables & Coefficient & t-count & P-Value & Conclusion \\
\hline $\begin{array}{c}\text { E-Service Quality }>>\text { Customer } \\
\text { Satisfaction }\end{array}$ & 0.241 & 2,141 & $\mathbf{0 . 0 3 3}$ & Received \\
\hline $\begin{array}{c}\text { Price }>>\text { Customer Satisfaction } \\
\text { Brand Awareness }>>\text { Customer } \\
\text { Satisfaction }\end{array}$ & 0.110 & 1,896 & $\mathbf{0 . 3 0 5}$ & Rejected \\
\hline
\end{tabular}

Source: Data Processed (2020)

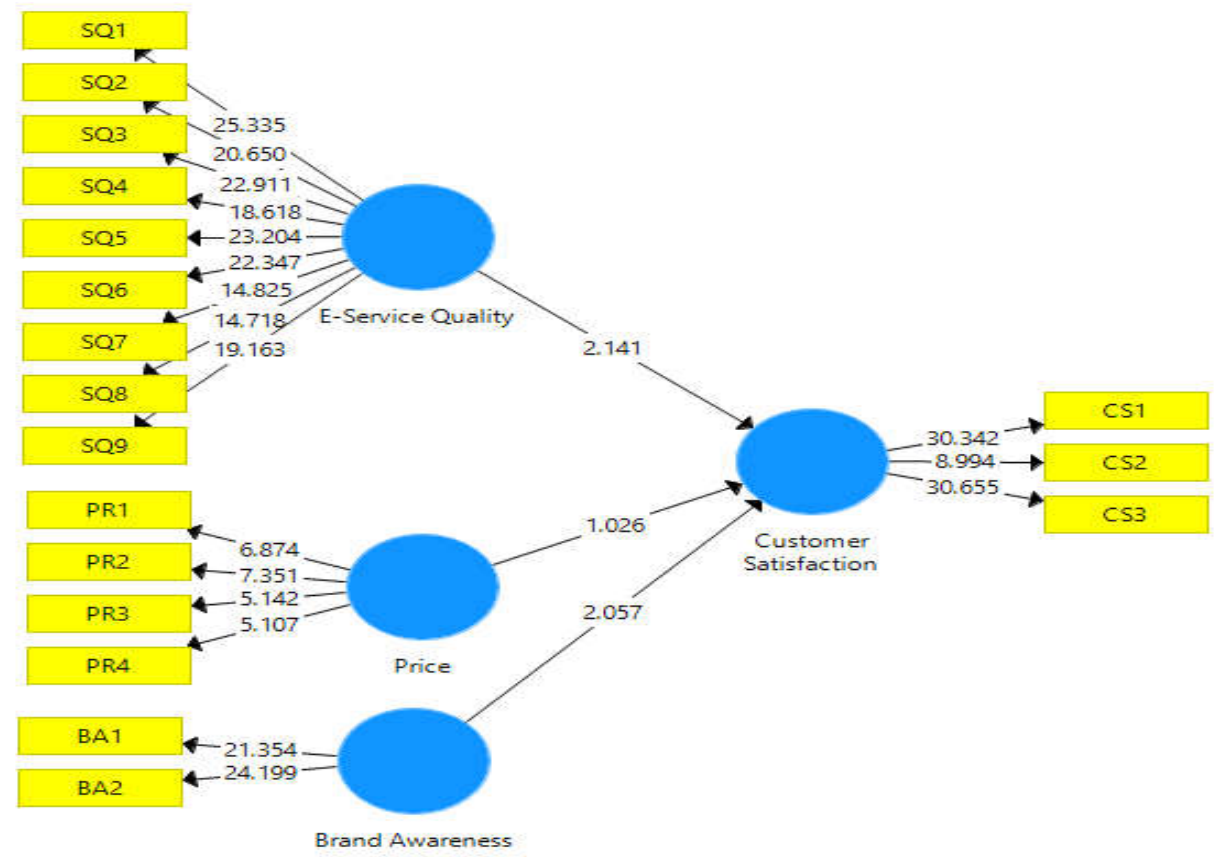

Figure 2. Hypothesis Test Results

In the significance test of the direct interaction between exogenous and endogenous variables, based on the processed data provided in Table 3 and Figure 2 above, it can be said that complete exogenous variables have a major impact on endogenous variables, even if there is one exogenous variable that does not affect the endogenous variable. Of the 3 hypotheses developed, 1 hypothesis was rejected, namely for the effect of the price variable on the customer satisfaction variable, the results of which did not have a significant effect. As for the variables of e-service quality and price have a significant effect on customer satisfaction.

\subsection{Discussion}

\subsubsection{E-service Quality on Customer Satisfaction}

Based on the results of the tests that have been done, the results show that e-service quality has a significant positive effect on customer satisfaction with a p-value of $0.033(<0.05)$, thus it can be concluded that hypothesis 1 can be accepted. Consumer perception about service plays a very important role. E-service quality will be fulfilled if the service delivery process from service providers to Jaket users is following what is perceived (Pradana \& Sanaji, 2018). The 
quality of service provides fulfillment of the needs and desires of consumers in terms of the level of excellence of the service so that it can meet the expected customer satisfaction (Lie et al., 2019). Customers will perceive and have expectations regarding the performance of the Jaket application, whether the application can facilitate them effectively and efficiently. If the application performance matches or exceeds customer expectations, the customer will be satisfied and even very satisfied, and vice versa (Septiani, 2020). The results of this discussion are in line with the research by Puriwat \& Tripopsakul (2017) and Ramadania et al. (2020), states that there is a significant effect of e-service quality on customer satisfaction.

a. Price on customer satisfaction

Based on the results of the tests that have been done, it is found that the price has a positive but not significant effect on customer satisfaction with a p-value of 0.305 (> 0.05), thus it can be concluded that hypothesis 2 is rejected. Pricing plays an important role in the service marketing process. If the price is too expensive, the product in question will not be affordable by certain target markets or even the level of satisfaction will below. Conversely, if the price is too cheap, the company is difficult to get a profit or some consumers perceive the quality is bad (Rezki, Sukmawati, Elbiansyah, \& Riyana, 2019). In addition, consumers also always check price information and different brand names when making judgments on measures of quality, ease of use, usability, performance, durability, and status, the implications of which boil down to consumer satisfaction (Adnyana \& Suprapti, 2018). Even though the price provided is affordable, customers will always consider other aspects that predominantly influence their shopping and consumption patterns, such as the product quality factor (Sudirman, Halim, et al., 2020). The results of this discussion are in line with the research by Rivai, Suneni, \& Febrilia (2019) and Kurniawati, Irawan, \& Prasodjo (2019), which states that there is no significant effect of price on customer satisfaction.

b. Brand Awareness of customer satisfaction

Based on the results of the tests that have been done, it is found that the perceived value has a significant positive effect on e-satisfaction with a p-value of $0.040(<0.05)$, thus it can be concluded that hypothesis 3 can be accepted. It can be concluded that creating brand awareness is an important step for a company to promote its products and services. Good brand awareness will have implications for the level of consumer satisfaction which comes from the memory of using the product (Mahanani \& Sari, 2019). Thus, the Jaket application has provided good brand awareness so that it can be a major determinant of the success of the Jaket application to enter and survive in the minds of consumers (Novrianda, Maksum, \& Jasin, 2018). The results of this discussion are in line with the research by Darmawan (2019) and Putri \& Happy (2019), states that there is a significant effect of brand awareness on customer satisfaction.

\section{Conclusions and Recommendations}

In accordance with the results of hypothesis testing, the results of testing the e-service quality variable show a significant effect on customer satisfaction. Furthermore, the test results of the price variable show an insignificant effect on customer satisfaction. Then in the test results, the brand awareness variable shows a significant effect on customer satisfaction. Furthermore, seen from the R-square value of the endogenous variables, it means that there is a weak relationship between the variables of e-service quality, price, and brand awareness in explaining consumer satisfaction. For further research recommendations, it is better if it is necessary to increase the number of research samples so that it can be generalized properly and add research variables that are thought to affect the level of customer satisfaction. 


\section{Bibliography}

Adnyana, D. G. A., \& Suprapti, N. W. S. (2018). Pengaruh Kualitas Pelayanan Dan Persepsi Harga Terhadap Kepuasan Dan Loyalitas Pelanggan Gojek Di Kota Denpasar. E-Jurnal Manajemen Universitas Udayana, 7(11), 6041. https://doi.org/10.24843/ejmunud.2018.v07.i11.p09

Amalia, A., Waluyo, H., \& Dewi, R. (2014). Pengaruh Brand Awareness Dan Kualitas Produk Terhadap Loyalitas Pelanggan Melalui Kepuasan Pelanggan Sebagai Variabel Intervening Pada Kartu Gsm Prabayar Simpati (Studi Kasus Pada Konsumen Kecamatan Pedurungan). Jurnal Ilmu Administrasi Bisnis, 6(3), 45-56.

Anggraini, F., \& Budiarti, A. (2020). Pengaruh Harga, Promosi, Dan Kualitas Pelayanan Terhadap Loyalitas Pelanggan Dimediasi Kepuasan Pelanggan Pada Konsumen Gojek. Jurnal Pendidikan Ekonomi, 8(3), 86-94.

Anggriana, R., Qomariah, N., \& Santoso, B. (2017). Pengaruh Harga, Promosi, Kualitas Layanan Terhadap Kepuasan Pelanggan Jasa Ojek Online “OM-JEK” Jember. Jurnal Sains Manajemen Dan Bisnis Indonesia, 7(2), 137-156.

Ariowibowo, S., Wibowo, I., \& Safrianto, A. S. (2018). Pengaruh Kesadaran Merek Dan Pengalaman Merek Terhadap Kepuasan Pelanggan. Jurnal Manajemen Bisnis Krisnadwipayana, 6(2), 175-182.

Bandawaty, E., Huriyati, R., \& Dirgantari, P. D. (2020). Pengaruh Brand Image Dan E-Service Quality Terhadap Customer Satisfaction Bentuk Inovasi Pemasaran Bukalapak. Jurnal Bisnis Dan Manajemen, 7(1), 81-86.

Barreda, A. A., Bilgihan, A., Nusair, K., \& Okumus, F. (2015). Generating brand awareness in Online Social Networks. Computers in Human Behavior, 50, 600-609. https://doi.org/10.1016/j.chb.2015.03.023

Barrutia, J. M., Charterina, J., \& Gilsanz, A. (2009). E-service quality: An internal, multichannel and pure service perspective. Service Industries Journal, 29(12), 1707-1721. https://doi.org/10.1080/02642060902793508

Berliana, M., \& Zulestiana, D. A. (2020). Pengaruh E-Service Quality terhadap Customer Satisfaction dan Loyalty pada Pengguna Gopay di Indonesia. REMIK (Riset Dan E-Jurnal Manajemen Informatika Komputer), 4(2), 11. https://doi.org/10.33395/remik.v4i2.10532

Berlianto, M. P. (2017). Pengaruh Kualitas Layanan-E, Kepuasan-E, Dan Kepercayaan-E Terhadap Kesetiaan-E Pada Gojek. Business Management Journal, 13(1). https://doi.org/10.30813/bmj.v13i1.247

Caniago, C., Siregar, R. T., Julyanthry, J., \& Pakpahan, G. E. (2019). Pengaruh Kualitas Pelayanan Dan Harga Terhadap Kepuasan Konsumen Dengan Brand Image Sebagai Variabel Moderating Pada Toko Sinar Bintang Photo Pematangsiantar. SULTANIST: Jurnal Manajemen Dan Keuangan, 7(2), 21-31. https://doi.org/10.37403/sultanist.v7i2.151

Darmawan, D. (2019). Kualitas Produk, Kesadaran Merek dan Harga serta Pengaruhnya Terhadap Kepuasan Pelanggan. Jurnal Administrasi Bisnis, 8(2), 75-88. https://doi.org/10.14710/jab.v8i2.25267

Foroudi, P. (2018). Influence Of Brand Signature, Brand Awareness, Brand Attitude, Brand Reputation On Hotel Industry's Brand Performance. International Journal of Hospitality Management, 76, 271-285. https://doi.org/10.1016/j.ijhm.2018.05.016

Fure, H. (2013). Lokasi, Keberagaman Produk, Harga, Dan Kualitas Pelayanan Pengaruhnya Terhadap Minat Beli Pada Pasar Tradisional Bersehati Calaca. EMBA, 1(3), 273-283.

Hair, J. F. (2014). Multivariat Data Analysis 7th Edition. New Jersey: Pearson Prentice Hall.

Hernita, S. J., Sidik, W., \& Sanjaya, V. F. (2020). Pengaruh E-Service dan Kualitas Sistem terhadap Kepuasan Pengguna Sistem E-Learning dengan Moderasi Perceived Value. Target: Jurnal Manajemen Dan Bisnis, 2(2), 257-264.

Herrera, C. F., \& Blanco, C. F. (2011). Consequences Of Consumer Trust In PDO Food Products: The Role Of Familiarity. Journal of Product and Brand Management, 20(4), 282-296. https://doi.org/10.1108/10610421111148306

Jasakreta. (2021). Jasa Delivery Pematangsiantar. 
Karmila, W. N. A., \& Sunia, I. W. (2020). Pengaruh E-Service Quality , Word Of Mouth , Price , dan Promotion Terhadap Minat Konsumen Menggunakan Layanan Jasa Go-Jek ( Studi Kasus Pada Masyarakat Pengguna Go-Jek Di Kota Denpasar ). TIERS Information Technology Journal, 10(10), 41-54.

Kurniawati, T., Irawan, B., \& Prasodjo, A. (2019). Analisis Pengaruh Kualitas Pelayanan, Harga, dan Brand Image Terhadap Kepuasan Konsumen Restoran Pizza Hut Cabang Jember. EJournal Ekonomi Bisnis Dan Akuntansi, 6(2), 147. https://doi.org/10.19184/ejeba.v6i2.11159

Lie, D., Sudirman, A., Efendi, E., \& Butarbutar, M. (2019). Analysis of Mediation Effect Of Consumer Satisfaction On The Effect Of Service Quality, Price and Consumer Trust On Consumer Loyalty. INTERNATIONAL JOURNAL OF SCIENTIFIC \& TECHNOLOGY RESEARCH, $8(8), 421-428$.

Mahanani, E., \& Sari, B. (2019). Analisis Pengaruh Brand Awareness, Brand Loyalty dan Harga terhadap Kepuasan Pelanggan PT. Jico Agung Jakarta. Jurnal Akuntansi Dan Manajemen, 16(02), 194-207. https://doi.org/10.36406/jam.v16i02.242

Maulida, Z., \& Indah, D. R. (2020). Pengaruh Kesadaran Merek, Asosiasi Merek dan Perspesi Kualitas terhadap Kepuasan Konsumen dan Implikasinya terhadap Niat Membeli Ulang Vitamin Merek Holisticare Ester C pada Masa Pandemi Covid 19 di Banda Aceh. Jurnal Manajemen Dan Keuangan, 9(3), 332-351.

Novrianda, D., Maksum, C., \& Jasin, M. (2018). Pengaruh Brand Awareness, Brand Association, Brand Extention, dan Perceived Quality terhadap Costumer Satisfaction (Pemasang Iklan) melalui Brand Preference Sindo Media (MNC Group). Ekobisman-Jurnal Ekonomi Bisnis Dan Manajemen, 3(1), 1-14.

Pradana, M. D., \& Sanaji. (2018). Pengaruh E-Service Quality Dan Kemudagan Terhadap Niat Beli Ulang Dengan Kepuasan Sebagai Variabel Intervening. Jurnal Ilmu Manajemen, 6(1), 1-10.

Puriwat, W., \& Tripopsakul, S. (2017). The Impact Of E-Service Quality On Customer Satisfaction And Loyalty In Mobile Banking Usage: Case Study Of Thailand. Polish Journal of Management Studies, 15(2), 183-193. https://doi.org/10.17512/pjms.2017.15.2.17

Putri, F. N., \& Happy, D. (2019). Pengaruh Brand Awareness, Perceived Value, dan Brand Image Terhadap Customer Satisfaction. Jurnal Manajerial Dan Kewirausahaan, 1(4), 768-777.

Rahayu, P. F., \& Riana, D. (2020). Pengaruh Persepsi Manfaat, Kualitas Layanan, Dan Harga Terhadap Kepuasan Pelanggan Transportasi Online (Gojek) Pada Mahasiswa/I Fakultas Ekonomi Universitas Tridinanti Palembang. Jurnal Akuntanika, 6(1), 46-54.

Ramadania, Juniwati, \& Meilky, L. (2020). Interaksi E-Service Quality, Kesadaran Merek, Kepercayaan Dan Kepuasan Terhadap Minat Pembelian Kembali Dalam Transportasi OnLine Gojek. Matrik: Jurnal Manajemen, Strategi Bisnis Dan Kewirausahaan, 14(2), 267-282.

Rezki, M., Sukmawati, L., Elbiansyah, \& Riyana, D. (2019). Pengaruh Kualitas Layanan Dan Harga Terhadap Kepuasan Pelanggan Jasa Transportasi Ojek Online. Jurnal Pendidikan Tata Niaga (JPTN), 4(1), 50-57.

Rivai, A. K., Suneni, \& Febrilia, I. (2019). Pengaruh Kualitas Pelayanan, Harga Dan Citra Merek Terhadap Kepuasan Konsumen Pengguna Transportasi Ojek Online Grab. Riset Manajemen Sains Indonesia (JRMSI), 10(1), 204-225. https://doi.org/http://doi.org/10.21009/JRMSI

Rondonuwu, P. (2013). Kualitas Produk, Harga Dan Kualitas Layanan Pengaruhnya Terhadap Kepuasan Konsumen Pengguna Mobil Nissan March Pada Pt. Wahana Wirawan Manado. EMBA, 1(4), 718-728. https://doi.org/10.35794/emba.v1i4.2755

Salim, A., \& Nurdin, H. (2020). Lokasi, Kebergaman Produk, Harga dan Kualitas Pelayanan Pengaruhnya Terhadap Minat Beli Pada Pasar Raya Amahami (Kota Bima). Target : Jurnal Manajemen Bisnis, 2(1), 132-140. https://doi.org/10.30812/target.v2i1.740

Santos, J. (2003). E-service Quality: A model of Virtual Service Quality Dimensions. Managing Service Quality: An International Journal, 13(3), 233-246. https://doi.org/10.1108/09604520310476490

Sarwono, J. (2016). Membuat Skripsi, Tesis dan Disertasi dengan Partial Least Square SEM (PLS SEM). Yogyakarta: Andi Offset. 
Septiani, R. (2020). Pengaruh E-Service Quality, Persepsi Harga, Dan Promosi Penjualan Terhadap Loyalitas Pelanggan Melalui Kepuasan Pelanggan. Jurnal Ilmu Manajemen, 17(1), 98-108.

Sianipar, G. J. . (2019). TRANSPORTASI OJEK ONLINE ( Studi Pada Pelanggan GrabBike Di Kota Medan ). Jurnal Manajemen Dan Bisnis (Jmb), 19, 183-196.

Sudirman, A., Efendi, E., \& Harini, S. (2020). Kontribusi harga dan kepercayaan konsumen untuk membentuk kepuasan pengguna transportasi berbasis aplikasi. Journal of Business and Banking, 9(2), 323-335. https://doi.org/10.14414/jbb.v9i2.2078

Sudirman, A., Halim, F., \& Pinem, R. J. (2020). Kepercayaan Sebagai Pemediasi Dampak Citra Merek dan Harga Terhadap Kepuasan Konsumen Gojek. Jurnal Pemasaran Kompetitif, 3(3), 66-76.

Sudirman, A., Sherly, Butarbutar, M., Nababan, S. T., \& Puspitasari, D. (2020). Loyalitas Pelanggan Pengguna Gojek Ditinjau Dari Aspek Kualitas Pelayanan dan Kepuasan Konsumen. Procuration: Jurnal Ilmiah Manajemen, 8(1), 63-73.

Sukirno, S., Aulawi, H., \& Widiawati, K. (2019). E-Service Quality Ojek Online Terhadap Customer Retension. IKRA-ITH HUMANIORA: Jurnal Sosial Dan Humaniora, 3(1), 30-38.

Suprapti, S., \& Suparmi. (2020). Membangun e-Loyality dan e-Satisfaction melalui e-Service Quality Pengguna Goride Kota Semarang. JKBM (Jurnal Konsep Bisnis Dan Manajemen), 6(2), 240-255. https://doi.org/10.31289/jkbm.v6i2.3795

Surucu, Ö., Özturk, Y., Okumus, F., \& Bilgihan, A. (2019). Brand Awareness, Image, Physical Quality And Employee Behavior As Building Blocks Of Customer-Based Brand Equity: Consequences In The Hotel Context. Journal of Hospitality and Tourism Management, 40(July), 114-124. https://doi.org/10.1016/j.jhtm.2019.07.002

Valkenburg, P. M., \& Buijzen, M. (2005). Identifying Determinants Of Young Children's Brand Awareness: Television, Parents, And Peers. Journal of Applied Developmental Psychology, 26(4), 456-468. https://doi.org/10.1016/j.appdev.2005.04.004

Yulianto, Y. (2021). Hubungan Antara Kualitas Produk , Harga , dan Kesadaran Merek terhadap Kepuasan Konsumen Produk GIG by Indosat Ooredoo di Apartemen Kalibata City Tahun. Urban Communication and Development Journal, 1(1), 21-26.

Zehir, C., \& Narcıkara, E. (2016). E-Service Quality and E-Recovery Service Quality: Effects on Value Perceptions and Loyalty Intentions. Procedia - Social and Behavioral Sciences, 229, 427-443. https://doi.org/10.1016/j.sbspro.2016.07.153 
